\title{
NEW RECORDS OF SNAKES (Squamata: Serpentes) FROM DIEN BIEN PROVINCE
}

\author{
Le Trung Dung ${ }^{1}$, Nguyen Lan Hung Son ${ }^{1}$, Pham The Cuong ${ }^{2}$, Nguyen Quang Truong ${ }^{2}$ \\ ${ }^{1}$ Hanoi National University of Education, *letrungdung_sp@hnue.edu.vn \\ ${ }^{2}$ Institute of Ecology and Biological Resources, VAST
}

\begin{abstract}
Based on a new herpetological collection from Muong Nhe Nature Reserve we added 13 new provincial records of snakes found in Dien Bien province, viz., Boiga cyanea, Dendrelaphis ngansonensis, Gonysoma prasinum, Lycodon futsingensis, Oligodon fasciolatus, Oreocryptophis porphyraceus, Rhabdophis nuchalis, $R$. subminiatus, Psammodynastes pulverulentus, Pareas carinatus, P. hamptoni, Pseudoxenodon macrops and Ovophis monticola. Our findings increase the species number of snakes to 46 in Dien Bien province.
\end{abstract}

Keywords: Distribution, morphology, new records, snakes, redescription, Dien Bien province.

\section{INTRODUCTION}

Muong Nhe Nature Reserve is located in the extreme northwest of Vietnam. The nature reserve is bounded by the international border with Laos in the west and the international border with China in the north [14]. The total area of this nature reserve is approximately $46,000 \mathrm{ha}$, consisting of 26,000 ha of evergreen forest in the core zone and 20,000 ha of disturbed secondary forest [3].

In terms of the herpetofaunal diversity, Dien Bien province is one of the most poorly studied provinces in Vietnam. Nguyen Van Sang (1991) [6] reported a total of 36 species of reptiles from Dien Bien province, including 24 species of snakes. Do Thanh Trung and Le Nguyen Ngat (2009) [4] documented 39 reptile species with a list of 23 species of snakes from Tua Chua district. We herein report 13 additional species for the snake fauna of Dien Bien province based on newly collected specimens from Muong Nhe Nature Reserve, comprising 12 species of the family Colobridae and one species of the family Viperidae.

\section{MATERIALS AND METHODS}

Field surveys were conducted in the Muong Nhe Nature Reserve, Dien Bien province by Le Trung Dung, Nguyen Lan Hung Son, Vu Thi Phuong Hoa, Bui Thi Ngat, Nguyen Viet Bach (hereafter LTD et al.) from May 2012 to June 2014, and by Nguyen Quang Truong, Le Trung
Dung, Pham The Cuong, Ngo Ngoc Hai (hereafter NQT et al.) in September 2014. Specimens were collected by hand or snake hook between 9:00-23:00. Specimens were fixed in $90 \%$ ethanol and subsequently transferred into $70 \%$ ethanol. Preserved specimens were deposited in the collection of the Hanoi National University of Education (HNUE) and the Institute of Ecology and Biological Resources (IEBR), Hanoi, Vietnam.

Abbreviation are as follows: SVL (snoutvent length): from tip of snout to anterior margin of cloaca; TaL (Tail length): from posterior margin of cloaca to tip of tail; a.s.l.: above sea level. Bilateral scale counts were given as left/right.

Taxonomic identifications were based on literature: Bourret (1936) [1], Smith (1943) [13], Ziegler et al. (1999) [18], Pauwels et al. (2002) [10], Nguyen Van Sang (2007) [7], Vogel et al. (2009) [15], Das (2010) [2].

\section{RESULTS AND DISCUSSION}

\section{Family Colubridae}

\section{Boiga cyanea (Duméril, Birron \& Duméril, 1854)}

Green cat snake/ Ran rao xanh (Fig. 1a).

Specimen examined $(\mathrm{n}=1)$. One adult female HNUE MNR.9 (SVL $1224 \mathrm{~mm}$, TaL $393 \mathrm{~mm}$ ), collected by LTD et al. on 12 May 2012 in Phi Thy stream, Leng Su Sin sector, 
Muong Nhe Nature Reserve (22 19.090'N, $102^{\circ} 20.917^{\prime}$ E, elevation $620 \mathrm{~m}$ a.s.l.).

Morphological characters. Body elongated; head distinct from neck; internasals two, shorter than prefrontal; frontal shorter than parietal; pupil round; loreal single; preocular 1/1; postoculars 2/2; anterior temporals 2/2; posterior temporals 3/4; subpralabials $8 / 8$, fourth and fifth entering orbit, eight largest; infralabials 11/11, first to fifth (on left) and first to fourth (on right) bordering chin shields; dorsal scale rows 21-21-15, smooth; ventrals 246; cloacal undivided; subcaudals 128 , divided.

Coloration in life. Dorsal surface of head, body and tail brownish green; sides of head pale green; venter cream.

Ecological notes. The specimen was collected at 21:00 while acrossing Phi Thy stream. The surrounding habitat was evergreen forests of large hardwood and shrub.

Distribution. In Vietnam, this species was previously known from Lao Cai province in the North southwards to Kien Giang province [17]. Elsewhere, it is known from India, Bangladesh, Bhutan, Nepal, China, Myanmar, Laos, Thailand, Cambodia and Malaysia [9].

Dendrelaphis ngansonensis (Bourret, 1935)

Nganson bronzeback/Ran leo cay ngan son (Fig. 1b).

Specimen examined $(n=1)$. One adult male IEBR A.2015.14 (SVL 934 mm, TaL 436 mm), collected by NQT et al. on 10 September 2014 in Phi Thy stream, Leng Su Sin sector, Muong Nhe Nature Reserve $\left(22^{\circ} 19.752^{\prime} \mathrm{N}\right.$, $102^{\circ} 21.010^{\prime} \mathrm{E}$, elevation $559 \mathrm{~m}$ a.s.l.).

Morphological characters. Body long; head small, distinct from neck; snout long; internasal longer than width and longer than prefrontal; frontal shorter than parietal; pupil round; loreal present; preocular $1 / 1$; postoculars $2 / 2$; anterior temporals $2 / 2$; posterior temporals 3/3; subpralabials 9/9, fourth and sixth entering orbit, seventh largest; infralabials 11/10, first to sixth bordering chin shields; dorsal scale rows 13-15-11, smooth; ventrals 192; cloacal divided; subcaudals 140, divided.
Coloration in life. Dorsal surface of head, body and tail reddish brown; two black stripes on neck; venter cream.

Ecological notes. The specimen was collected at 19:00 on bamboo branches, ca. $2 \mathrm{~m}$ above the water in a rocky stream. The surrounding habitat was evergreen forest of large hardwoods and shrubs.

Distribution. In Vietnam, this species has been known from Ha Giang Province in the North southwards to Quang Nam Province [9]. Elsewhere, this species is known from Laos [9].

\section{Gonyosoma prasinum (Blyth, 1854)}

Green Trinket Snake/Ran soc xanh (Fig. 1c).

Specimens examined $(n=2)$. One adult male HNUE MNR.77 (SVL 545 mm, TaL 204 mm) and one subadult female HNUE MNR.58 (SVL $246 \mathrm{~mm}$, TaL $80 \mathrm{~mm}$ ), collected by LTD et al. on 18 March 2014 in Pac Ma stream, Leng Su Sin sector, Muong Nhe Nature Reserve $\left(22^{\circ} 18.783^{\prime} \mathrm{N}, 102^{\circ} 20.217^{\prime} \mathrm{E}\right.$, elevation $794 \mathrm{~m}$ a.s.1.).

Morphological characters. Body cylindrical; head slightly distinct from neck; snout round; eye large, pupil round; rostral broader than high; internasals two, smaller than the prefontals; parietals longer than wide; nasal undivided; preocular 1/1; postoculars 2/2; anterior temporals $2 / 2$; posterior temporals $2 / 3$; subpralabials $9 / 9$, fourth to fifth entering orbit, eight largest; infralabials 10/10, first to fifth bordering chin shields; dorsal scale rows 19-1915, weakly keeled; ventrals 182-199; cloacal divided; subcaudals 93-101, divided.

Coloration in life. Dorsal surface uniformly green, the tip of tail brown; labials yellowishgreen; venter pale green; a faint dark postocular stripe present; iris yellow.

Ecological notes. The specimens were collected after raining, at 9:00 and at 21:00 on the ground, near Pa Ma stream. The surrounding habitat was evergreen secondary forest.

Distribution. In Vietnam, this species was previously known from Bac Kan, Thai Nguyen, Vinh Phuc, Nghe An, Quang Binh and Gia Lai provinces [9]. Elsewhere, this species is known 
from India, China, Myanmar, Laos, Thailand, and Malaysia [9].

Remarks. The specimens from Dien Bien differ from the description of Smith (1943) [12] in having fewer ventrals (182-199 versus 191209).

\section{Lycodon futsingensis (Pope, 1928)}

Futsing Wolf Snake/Ran khuyet fut-sing (Fig. 1d).

Specimen examined $(n=1)$. One adult male HNUE MNR.47 (SVL 651 mm, TaL 170 mm), collected by LTD et al. on 21 November 2013 in Chung Chai sector, Muong Nhe Nature Reserve $\left(22^{\circ} 10.083^{\prime} \mathrm{N}, 102^{\circ} 18.800^{\prime} \mathrm{E}\right.$, elevation $1057 \mathrm{~m}$ a.s.1.).

Morphological characters. Head distinct from neck; snout long; pupil vertically elliptic; rostral large; internasals two, not touching loreal and preocular; frontal hexagonal; parietals longer than wide; nasal divided; loreal single; preocular $1 / 1$; postoculars $2 / 2$; anterior temporals $2 / 2$; posterior temporals $3 / 3$; subpralabials $8 / 8$, third and fifth entering orbit, sixth largest; infralabials $10 / 10$, first to fifth chin shields; dorsal scale rows 17-17-15, smooth; ventrals 223; cloacal undivided; subcaudals 86 , divided.

Coloration in life. Dorsal surface of body and tail brownish grey to dark brown, with 30 light brown bands on body, 17 bands on tail; first band starting at ventral 20; some bands in Y-shape, more distinct in posterior part of body; head grey with a lighter band, from eye to neck; belly cream, posterior part mottled; lower surface of tail dark brown.

Ecological notes. The specimen was collected at 20:00 on a tree branch, ca. $1.2 \mathrm{~m}$ above the water surface of stream. The surrounding habitat was evergreen secondary forest of small hardwoods and shrubs.

Distribution. In Vietnam, this species has been known from Bac Giang and Lao Cai provinces in the North southwards to Quang Binh and Da Nang [5, 9]. Elsewhere, this species is known from China [9].

\section{Oligodon fasciolatus (Günther, 1864)}

Fasciolated Kukri Snake/Ran khiem duoi vong (Fig. 2a).

Specimens examined $(n=3)$. Two adult males HNUE MNR.22 (SVL 495 mm, TaL 90 mm), HNUE MNR.23 (SVL 353 mm, TaL 61 $\mathrm{mm}$ ), collected on 12 June 2013 and one adult female HNUE MNR.72 (SVL 403 mm, TaL 49 $\mathrm{mm}$ ), collected on 23 June 2014, by LTD et al. in Muong Nhe sector, Muong Nhe Nature Reserve $\left(22^{\circ} 13.582^{\prime} \mathrm{N}, 102^{\circ} 22.532^{\prime} \mathrm{E}\right.$, elevation $823 \mathrm{~m}$ a.s.1.).

Morphological characters. Body stout; snout round; head short, indistinct from neck; eye moderate in size, pupil round; internasals two, as wide as prefontals; parietals longer than wide; nasal undivided; preoculars 1/1 (HNUE MNA.23, 72) or 2/2 (HNUE MNA.22); postoculars $2 / 2$; anterior temporal $1 / 1$; posterior temporals $2 / 2$; subpralabials $8 / 8$, fourth and fifth entering orbit, sixth largest; infralabials 10/10, first to fifth bordering chin shields; dorsal scale rows 21-21-17(15), smooth; ventrals 179-197; cloacal individed; subcaudals 37-51, divided.

Coloration in preservative. Dorsal surface of body dark brown with a narrow vertebral stripe and two broader dorsolateral stripes along the body; dorsal head dark brown with two streaks, anterior one extending from prefrontals downwards on each side through the eyes to fifth-sixth subpralabials, posterior one extending from parietals to the neck; parietals with dark brown spots; venter and lower surface of tail pale yellow.

Ecological notes. The specimens were collected between 20:00 and 22:00 on the ground, in the disturbed secondary forest.

Distribution. In Vietnam, this species has been recorded from Lai Chau and Cao Bang provinces in the North southwards to $\mathrm{Ca} \mathrm{Mau}$ Province [9]. Elsewhere, the species is known from Myanmar, Laos, Thailand and Cambodia [9].

Remarks. The specimens from Dien Bien differ from the descriptions of Pauwels et al. (2002) [10] and Das (2010) [2] in the absence of dark blotches on dorsum and having more ventrals (179-197 versus 160-190). 


\section{Oreocryptophis porphyraceus (Cantor, 1839)}

Black-banded Trinket Snake/Ran soc dom do (Fig. 2b).

Specimen examined $(n=1)$. One adult male HNUE MNR.8 (SVL 666 mm, TaL $161 \mathrm{~mm}$ ), collected by LTD et al. on 14 May 2012 in Pac Ma stream, Leng Su Sin sector, Muong Nhe Nature Reserve $\left(22^{\circ} 18.783^{\prime} \mathrm{N}, 102^{\circ} 20.217^{\prime} \mathrm{E}\right.$, elevation $794 \mathrm{~m}$ a.s.l.).
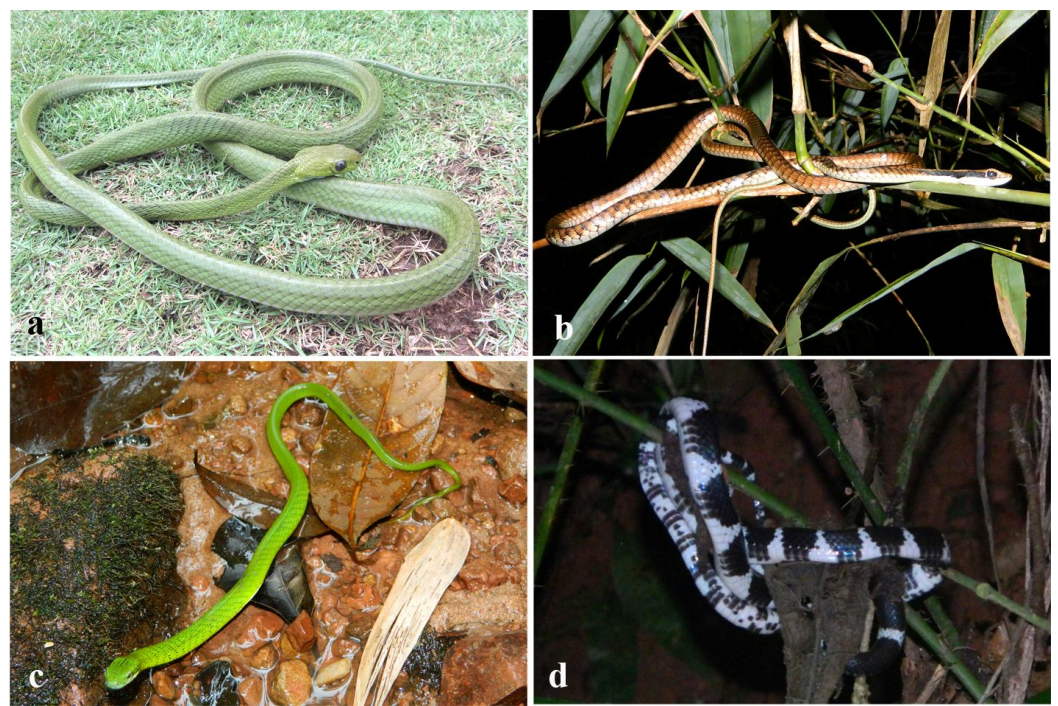

Figure 1. (a) Boiga cyanea (HNUE MNR.9, adult male);

(b) Dendrelaphis ngansonensis (IEBR A.2015.14, adult male); (c) Gonyosoma prasinum (HNUE MNR.58, subadult female); (d) Lycodon futsingensis (HNUE MNR.47, adult male)
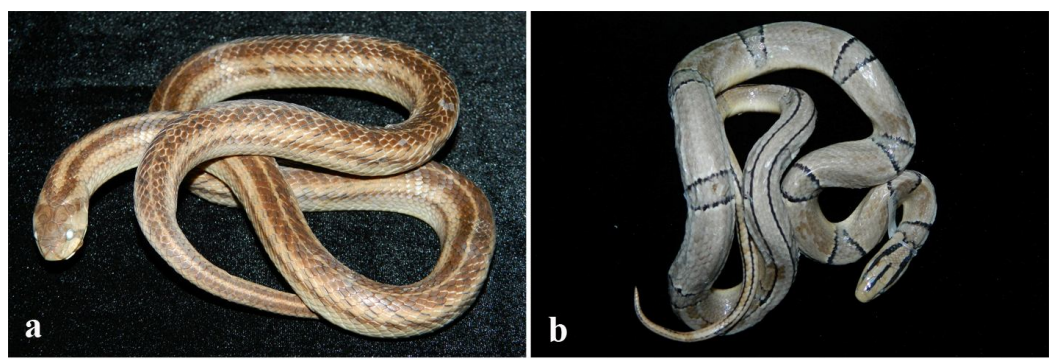

Figure 2. (a) Oligodon fasciolatus (HNUE MNR.23, adult male); (b) Oreocryptophis porphyraceus (HNUE
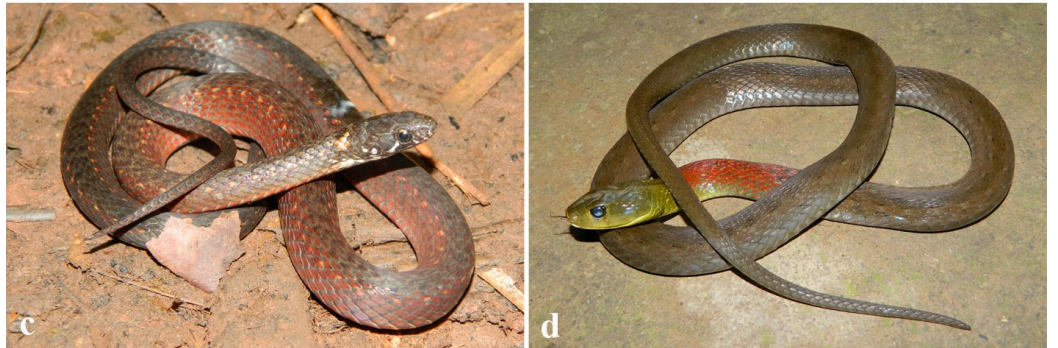
MNR.8, adult male); (c) Rhabdophis nuchalis (IEBR A.2015.15, subadult female); (d) Rhabdophis subminiatus (IEBR A.2015.15, adult female)

Morphological characters. Head elongated, indistinct from neck; snout round; internasals two, shorter than prefrontal; frontal shorter than parietal; eye small, pupil round; loreal single; preocular $1 / 1$; postoculars $2 / 2$; anterior temporal $1 / 1$; posterior temporals $2 / 2$; subpralabials $8 / 8$, fourth and fifth entering orbit, seventh largest; infralabials $10 / 10$, first to fourth bordering chin shields; dorsal scale rows 19-19-17, smooth; ventrals 195; cloacal divided; subcaudals 68, divided.

Coloration in preservative. Dorsal surface of body and tail redlish-brown with 18 dark bands, edged in black anteriorly and posteriorly; two black stripes extending from behind eyes to neck and another on dorsal head; venter cream. 
Ecological notes. The specimen was collected at 20:00 on the ground, near a stream, in the evergreen forest.

Distribution. In Vietnam, this species has been known from several provinces in the North: Lao Cai, Cao Bang, Bac Kan, Lang Son, Thai Nguyen, Vinh Phuc, Son La and Quang Binh [9]. Elsewhere, this species is known from India, Nepal, China, Taiwan, Myanmar, Laos, Thailand, Cambodia, Malaysia and Indonesia [9].

Remarks. According to Das (2010) [2], the specimen from Dien Bien could be assigned to the subspecies $O$. p. vaillanti.

\section{Rhabdophis nuchalis (Boulenger, 1891)}

Hubei Keelback/Ran hoa co gay (Fig. 2c)

Specimen examined $(n=1)$. One subadult female IEBR A.2015.15 (SVL 289 mm, TaL $110 \mathrm{~mm}$ ), collected by NQT et al. on 13 September 2014, near Hang Doi moutain, Nam Po village, Muong Nhe sector, Muong Nhe Nature Reserve $\left(22^{\circ} 08.996\right.$ 'N, $102^{\circ} 26.542^{\prime} \mathrm{E}$, elevation $905 \mathrm{~m}$ a.s.1.).

Morphological characters. Head flat, distinct from neck; nuchal groove distinct; snout round; internasal shorter than prefrontal; frontal shorter than parietal; eye moderate, pupil round; loreal single; preocular $1 / 1$; postoculars $2 / 2$; anterior temporal 1/1; posterior temporals $2 / 2$; subpralabials $6 / 6$, thirdth and fourth entering orbit, fifth largest; infralabials $7 / 7$, first to fourth bordering chin shields; dorsal scale rows 17-1715, smooth; ventrals 134; cloacal divided; subcaudals 64, divided.

Coloration in life. Dorsal surface of body and tail grey with reddish brown spots; head dark grey speckled with pale yellow; neck with a large yellow spot on each side, temporal region with some white spots behind eye; venter cream with black stripe on outer edges.

Ecological notes. The specimen was collected at 6:30 on the ground near a stream in the secondary forest.

Distribution. In Vietnam, this species has been known from several provinces in the North: Lao Cai, Cao Bang and Vinh Phuc [9].
Elsewhere, this species is known from India, China, Myanmar, and Laos [9].

Remarks. The specimen from Dien Bien differs from the description of Das (2010) [2] in having fewer ventrals (134 versus 152-156).

\section{Rhabdophis subminiatus (Schlegel, 1837)} 2d).

Red-necked Keelback/Ran hoa co nho (Fig.

Specimen examined $(\mathrm{n}=1)$. One adult female IEBR A.2015.16 (SVL 653mm, TaL 153 $\mathrm{mm})$, collected by LTD and PTC on 19 September 2014 in the forest near Ta Lo San village, Sen Thuong commune, in buffer zone of Muong Nhe Nature Reserve $\left(22^{\circ} 29.613^{\prime} \mathrm{N}\right.$, $102^{\circ} 17.553^{\prime} \mathrm{E}$, elevation $1088 \mathrm{~m}$ a.s.1.).

Morphological characters. Head large, distinct from neck; snout round; internasal longer than prefrontal; frontal shorter than parietal; eye moderate, pupil round; loreal single; preocular $1 / 1$; postoculars $3 / 3$; anterior temporals $2 / 2$; posterior temporals $3 / 3$; subpralabials $8 / 8$, third and fifth entering orbit, the sixth largest; infralabials $10 / 10$, first to fifth bordering chin shields; dorsal scale rows 17-1917, keeled; ventrals 164; cloacal divided; subcaudals 57 , divided.

Coloration in life. Dorsal surface of olive; not black reticulation on the back of neck; nape with red band; venter white pink with black on outer edges.

Ecological notes. The specimen was collected at 21:00 on the branches of shrubs near the a stream in the secondary forest.

Distribution. This is a widespread species in Vietnam, known from Lao Cai in the North southward to Kien Giang province [8]. Elsewhere, this species is known from India, China, Myanmar, and Laos [8].

Remarks. The specimen from Dien Bien can be assigned to the subspecies $R$. s. helleri, however it differs from the description of Das (2010) [2] in having fewer ventrals (57 versus 64-96).

Psammodynastes pulverulentus (Boie, 1827)

Mock Viper/Ran ho dat nau (Fig. 3a)

Specimen examined $(n=1)$. One adult 
female HNUE MNR.7 (SVL 326 mm, TaL 68 $\mathrm{mm}$ ) by LTD et al. on 8 May 2012 in Y Ma Ho stream, Sin Thau sector, Muong Nhe Nature Reserve $\left(22^{\circ} 19.197^{\prime} \mathrm{N}, 102^{\circ} 11.505^{\prime} \mathrm{E}\right.$, elevation 1557 m a.s.l.).

Morphological characters. Head triangular, distinct from neck; eye moderately, pupil round; snout pointed; internasals two, wider than long, not in contact with loreal; nasal undivided; parietals longer than wide; loreal single, not contact with orbit; preoculars $2 / 2$; postoculars $2 / 2$, bodering anterior temporals; anterior temporals $2 / 2$; posterior temporals $2 / 2$; subpralabials $8 / 8$, third to fifth entering orbit, sixth largest; infralabials $7 / 7$, first to third bordering chin shields; dorsal scale rows 17-1715, smooth; ventrals 166; cloacal undivided; subcaudals 54 , divided.
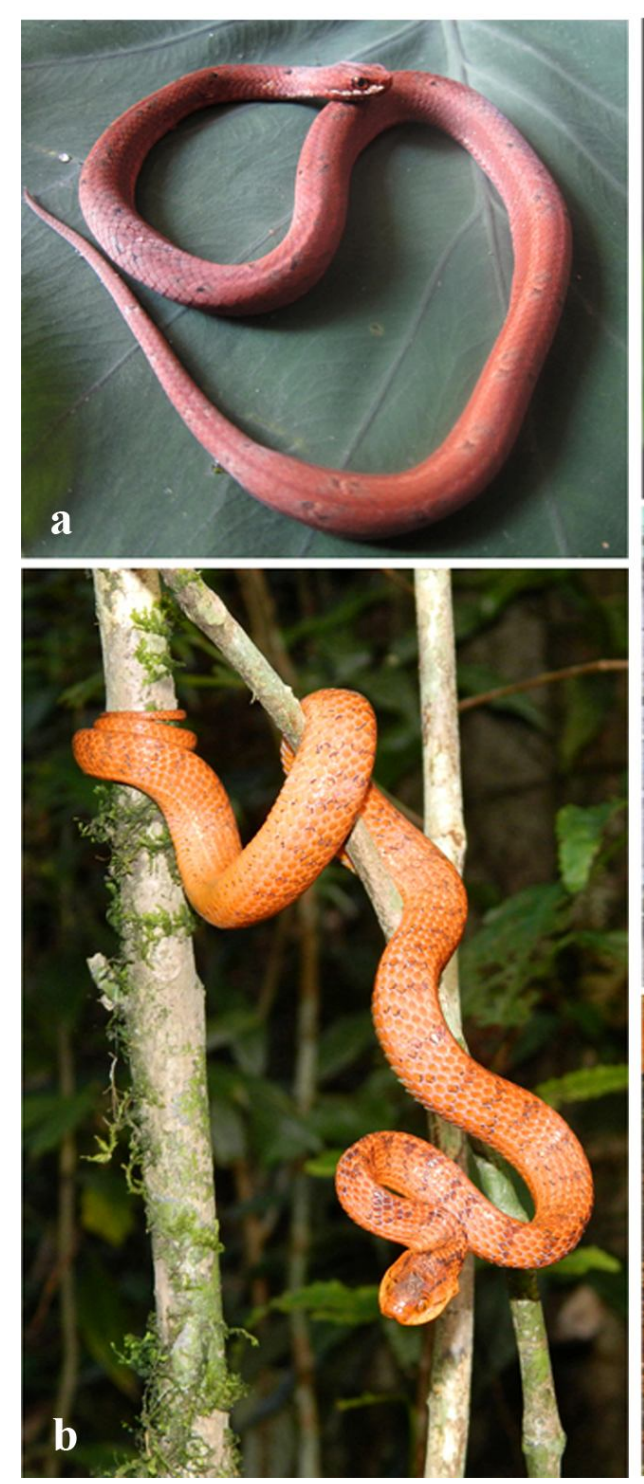
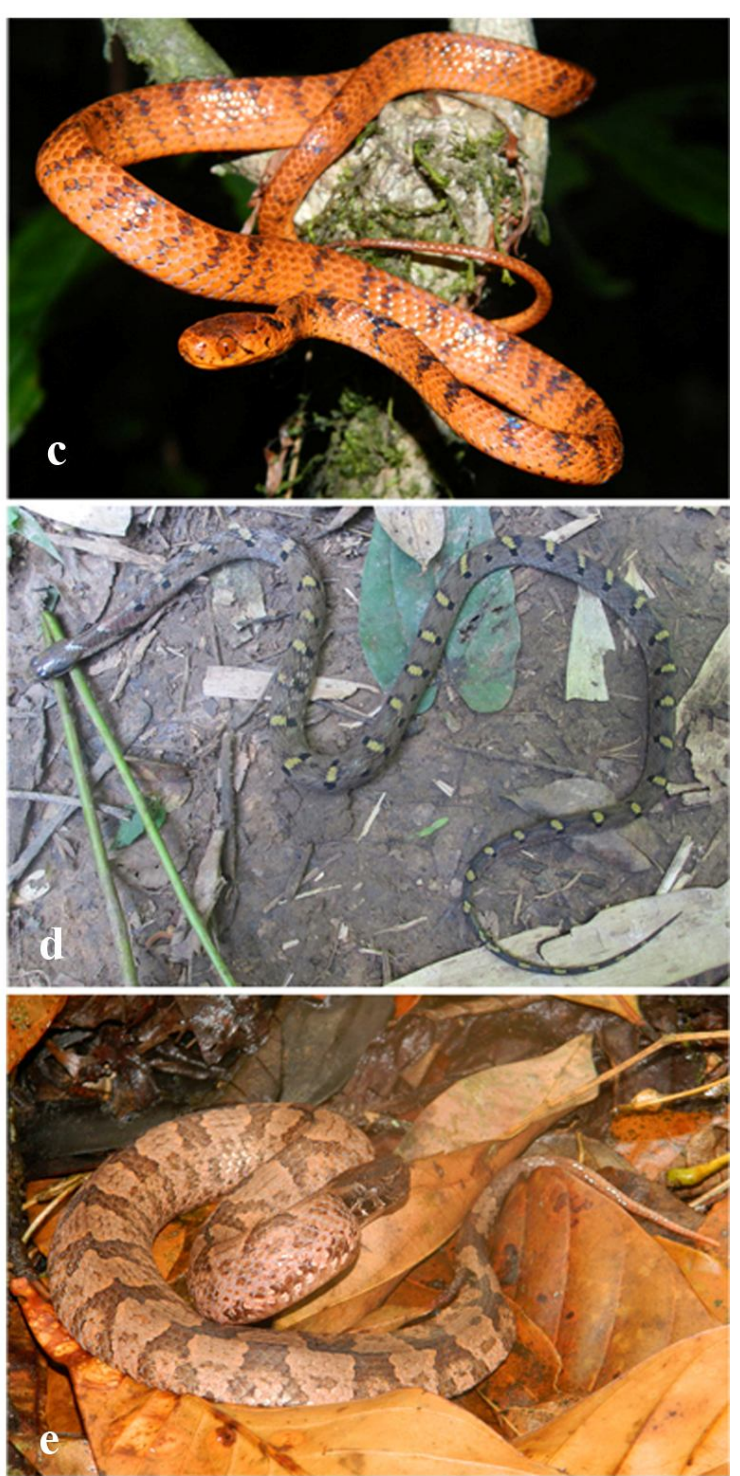

Figure 3. (a) Psammodynastes pulverulentus (HNUE MNR.7, adult female) (b) Pareas carinatus (HNUE MNR.15, adult female); (c) Pareas hamptoni (HNUE MNR.13, adult male); (d) Pseudoxenodon macrops (HNUE MNR.39, adult male); (e) Ovophis monticola (HNUE MNR.57, adult male) 
Coloration in life. Dorsal surface of head, body and tail reddish brown, with some black spots and indistinct light bands, edged in black; dorsal head with some dark stripe; lateral head with a white streak from behind nostril to the neck; venter cream.

Ecological notes. The specimen was collected at 9:00 on the ground, near a stream. The surrounding habitat was secondary forest of small hardwoods and shrubs.

Distribution. In Vietnam, this species has been recorded from Bac Kan and Quang Ninh provinces in the North southwards to Dong Nai and Tay Ninh provinces [9]. Elsewhere, this species is known from India, Nepal, Bangladesh, Bhutan, China, Taiwan, Myanmar, Laos, Thailand, Cambodia, Malaysia, Indonesia, and Philippines [9].

\section{Pareas carinatus (Boie, 1828)}

Keeled Slug Snake/Ran ho may go (Fig. 3b)

Specimen examined $(n=1)$. One adult female HNUE MNR.15 (SVL $429 \mathrm{~mm}, \mathrm{TaL}$ $103 \mathrm{~mm}$ ), collected by LTD et al. on 17 February 2013 near Y Ma Ho stream, Sin Thau sector, Muong Nhe Nature Reserve $\left(22^{\circ} 22.050^{\prime} \mathrm{N}, 102^{\circ} 10.683^{\prime} \mathrm{E}\right.$, elevation $1657 \mathrm{~m}$ a.s.1.).

Morphological characters. Head short, distinct from neck; snout projecting beyond lower jaw; internasals two, wider than long, as long as prefrontal, in contact with loreal; prefontal not in contact with loreal; frontal as long as parietal; eye large, pupil vertically elliptic; loreal present; preoculars $2 / 2$; postoculars $1 / 1 ;$ anterior temporals $2 / 2$; posterior temporals $2 / 3$; subpralabials $8 / 8$, fourth and fifth below eyes but not entering orbit, seventh largest; infralabials 9/9, first to third bordering chin shields; dorsal scale rows 15-15-15, median series weakly keeled; ventrals 186; cloacal undivided; subcaudals 75, divided.

Coloration in life. Dorsal surface reddish brown with indistinct transverse black bars; a black streak extending from behind the eye to the neck; ventrals yellow with black spots on outer edges.
Ecological notes. The specimen was collected at 20:00 on a tree branch, ca. $1.5 \mathrm{~m}$ above the forest floor, near a stream. The surrounding habitat was evergreen secondary forest of small hardwoods and shrubs.

Distribution. In Vietnam, this species has been known from Son $\mathrm{La}$ and Vinh Phuc provinces in the North southwards to Dong Nai and Tay Ninh provinces [9]. Elsewhere, it is known from China, Myanmar, Laos, Thailand, Cambodia, Malaysia and Indonesia [9].

Remarks. The specimen from Dien Bien differs from the description of Smith (1943) [13] in having more ventrals (186 versus 170184).

\section{Pareas hamptoni (Boulenger, 1905)}

Hampton's Slug Snake/Ran ho may ham-ton (Fig. 3c).

Specimen examined $(\mathrm{n}=1)$. One adult male HNUE MNR.13 (SVL 346 mm, TaL 104 mm), collected by hereafter LTD et al. on 17 February 2013, near Y Ma Ho stream, Sin Thau sector, Muong Nhe Nature Reserve $\left(22^{\circ} 22.050^{\prime} \mathrm{N}\right.$, $102^{\circ} 10.683$ 'E, elevation $1657 \mathrm{~m}$ a.s.l.).

Morphological characters. Head short, distinct from neck; snout projecting beyond lower jaw; internasals two, wider than long, shorter than prefrontal, in contact with loreal; prefontal in contact with loreal; frontal shorter than parietal; eye large, pupil vertically elliptic; loreal single; preoculars $2 / 2$; postocular $1 / 1$; anterior temporals $2 / 2$; posterior temporals $3 / 3$; subpralabials $7 / 7$, third and fourth below eyes but not entering orbit, seventh largest; infralabials 9/9, first to third bordering chin shields; dorsal scale rows 13-15-15, smooth; ventrals 187; cloacal undivided; subcaudals 92, divided.

Coloration in life. Dorsal surface of head, body and tail light brown with irregular black crossbars; dorsal head with black spots; ventrals yellow with black spots on outer edges.

Ecological notes. The specimen was collected at 21:00 on a tree branch, ca. $1.2 \mathrm{~m}$ above the forest floor, near a stream. The surrounding habitat was evergreen secondary forest of small hardwoods and shrubs. 
Distribution. This is a widespread species in Vietnam, known from Lao Cai and Ha Giang provinces in the North southwards to Lam Dong and Dong Nai provinces (Nguyen et al., 2009 [9]). Elsewhere, it is known from China, Myanmar, Laos, Cambodia [9].

Remarks. The specimen from Dien Bien differ from the description of Smith (1943) [13] in having fewer ventrals (187 versus 191-196). $P$. hamptoni is morphologically very similar to $P$. carinatus, however, they can be distinguished from each other by the arrangement of prefontal and loreal (in contact in $P$. hamptoni but not in contact in $P$. carinatus).

\section{Pseudoxenodon macrops (Blyth, 1855)}

Big-eyed Bamboo Snake/Ran ho xien mat to (Fig. 3d)

Specimens examined $(\mathrm{n}=2)$. One adult male HNUE MNR.39 (SVL 322 mm, TaL 36 $\mathrm{mm})$ and one adult female HNUE MNR.44 (SVL $664 \mathrm{~mm}$, TaL $137 \mathrm{~mm}$ ), collected by LTD et al. on 15 October 2013 in Nam Ke sector, Muong Nhe Nature Reserve $\left(22^{\circ} 7.233^{\prime} \mathrm{N}\right.$, $102^{\circ} 28.350^{\prime} \mathrm{E}$, elevation $949 \mathrm{~m}$ a.s.l.).

Morphological characters. Body cyclindrical; head short, slightly distinct from neck; snout projecting beyond lower jaw; internasals two, shorter than prefrontal, not in contact with loreal; frontal shorter than parietal; eye large, pupil round; loreal present; preoculars $1 / 2$ in the male and $1 / 1$ in the female; postoculars $3 / 3$; anterior temporal $1 / 1$; posterior temporals $2 / 2$; subpralabials $8 / 8$, fourth and fifth entering orbit, seventh largest; infralabials $10 / 10$, first to fifth bordering chin shields; dorsal scale rows 19-17-15, keeled; ventrals 164 in the male and 169 in the female; cloacal undivided; subcaudals 31 in the male and 63 in the female, divided.

Coloration in life. Dorsal surface of body and tail brownish grey with a series of yellow crossbars, outer sides edeged in black; nape with a chevron-shaped dark marking; venter yellow with dark crossbars.

Ecological notes. The specimen was collected between 10:00 and 13:00 on the forest floor in the secondary forest.

Distribution. In Vietnam, this species has been known from Lai Chau and Lao Cai provinces in the North southwards to the Central Highlands (Nguyen et al., 2009 [9]). Elsewhere, this species is known from India, Nepal, China, Myanmar, Laos, Thailand, and Malaysia (Nguyen et al., 2009 [9])

Remarks. The specimens from Dien Bien differ from the descriptions of Smith (1943) [13] and Das (2010) [2] in having fewer subcaudals (31 versus 55-80).

\section{Family Viperidae}

\section{Ovophis monticola (Günther, 1864)}

Chinese Mountain Pitviper/Ran luc nui (Fig. 3e).

Specimens examined $\quad(\mathrm{n}=3)$. Three specimens were collected by LTD et al. in Muong Nhe Nature Reserve: one adult male HNUE MNR.57 (SVL $400 \mathrm{~mm}$, TaL $91 \mathrm{~mm}$ ), on 18 March 2014, and one adult female HNUE MNR.46 (SVL $497 \mathrm{~mm}$, TaL $133 \mathrm{~mm}$ ), on 21 November 2013, in Chung Chai sector $\left(22^{\circ} 10.083^{\prime} \mathrm{N}, 102^{\circ} 18.800^{\prime} \mathrm{E}\right.$, elevation $1057 \mathrm{~m}$ a.s.l.); one adult female HNUE MNR.17 (SVL $505 \mathrm{~mm}, \mathrm{TaL} 121 \mathrm{~mm}$ ), on 17 February 2013 in Sin Thau sector $\left(22^{\circ} 18.583^{\prime} \mathrm{N}, 102^{\circ} 10.950^{\prime} \mathrm{E}\right.$, elevation 1742 m a.s.l.).

Morphological characters. Body subcyclindrical; head distinct from neck; snout projecting beyond lower jaw, twice as long as the diameter of the eye; upper head scales small, smooth; internasal large, as wide as long, 2-3 enlarged scales in a line between internasals; supraoculars large, 6-8 scales in a line between them; prefontal contact with loreal; eye large, pupil vertically elliptic; preoculars 3/3; postoculars 3/3; temporal scales smooth; supralabials $8 / 8$, third largest; infralabials $10 / 10$ in the male and 11/11 in females, first to third bordering chin shields; dorsal scale rows 27-2119, strongly keeled; ventrals 131-139; cloacal undivided; subcaudals 51-57, divided.

Coloration in life. Dorsal surface of body and tail light brown with a series of black crossbars, smaller dark spots upon the sides; anterior part of head with yellow stripes; 
temporal region with a black streak; venter blackish brown.

Ecological notes. The specimens were collected between 20:00 and 22:00 on a rock in a stream in the forest and another one was found on the ground in forest edge. The surrounding habitat was evergreen secondary forest of small hardwoods and shrubs.

Distribution. In Vietnam, this species has been known from several provinces: Lao Cai, Lang Son, Vinh Phuc, Ha Tay, Quang Tri, Da Nang, Kon Tum, Dak Lak, and Lam Dong (Nguyen et al. 2009 [9]). Elsewhere, it is known from India, Nepal, Bangladesh, China, Taiwan, Myanmar, Laos, Thailand, Cambodia, Malaysia and Indonesia [9].

\section{CONCLUSION}

As a result of this study, the diversity of the snake fauna of Dien Bien province has been increased $29 \%$ in comparison with the species lists of Nguyen Van Sang (1991) [6] and Do Thanh Trung and Le Nguyen Ngat (2009) [4]. However, among 24 species recorded in Muong Nhe Nature Reserve by Nguyen Van Sang (1991) [6], we have not found voucher specimens of the following species: Ptyas mucosa (Linnaeus, 1758), Rhabdophis chrysargos (Schlegel, 1837), Euprepiophis mandarinus (Cantor, 1842), and Sinomicrurus kellogi (Pope, 1928). In Son La, a neighboring province of Dien Bien, Pham et al. (2014) [11] recorded a total 51 species of snakes, including seven new provincial records. Species composition of the snake fauna of Dien Bien shares 36 species with that of Son La Province $[8,11,12]$. Moreover, the snake fauna of Dien Bien Province is also similar to that of Yunnan Province (China) with 41 species found in both provinces [16]. It is expected that additional new provincial and even country records of snakes will be discovered in Dien Bien province by further studies.

Acknowledgements: We are grateful to the directorate of the Muong Nhe Nature Reserve for support of our field work. We thank H. P. T. Vu, N. T. Bui, B. V. Nguyen (HNUE), H. N.
Ngo (VNMN) and K. L. Toan, C. T. Ly (Leng $\mathrm{Su}$ Sin Commune) for their assistance in the field. This research is funded by Vietnam National Foundation for Science and Technology Development (NAFOSTED) under grant number 106-NN.05-2014.34. Field work and equipment was partially supported by the Idea Wild to D.T. Le. Research of T.Q. Nguyen in northwestern Vietnam is funded by the National Geographic Society (Grant No. 949214) and the Alexander von Humboldt Foundation (VIE 114344).

\section{REFERENCES}

1. Bourret R., 1936. Les Serpentes de 1'Indochine. I. Études sur la Faune. Henri Basuyau \& Cie, Toulouse 1 \& 2: 141+ 505 p.

2. Das I., 2010. A field guide to the reptiles of South-East Asia (Hardback). New Holland Publishers, 376 p.

3. Department of Agriculture and Rural Development of Dien Bien, 2008. A revision of the investment plan for the period from 2008-2020 of Muong Nhe Nature Reserve. Technical Report (in Vietnamese).

4. Do Thanh Trung, Le Nguyen Ngat, 2009. The species composition of Amphibians and Reptiles in Tua Chua district, Dien Bien Province. Proceedings of the first national scientific workshop "Amphibia and Reptile in Vietnam": 153-158 (in Vietnamese, summary in English).

5. Hecht V. L., Pham T. C., Nguyen T. T., Nguyen Q. T., Bonkowski M., Ziegler T., 2013. First report on the herpetofauna of Tay Yen Tu Nature Reserve, northeastern Vietnam. Bodiversity Journal, 4(4): 507-552.

6. Nguyen Van Sang, 1991. The survey result of herpetofauna at Muong Nhe Nature Reserve, Lai Chau province. Technical report, Institute of Ecology and Biological Resources: 13 p. (in Vietnamese).

7. Nguyen Van Sang, 2007. Fauna of Vietnam: Serpentes. Science and Technics Publishing House, Hanoi, 247p. 
8. Nguyen Van Sang, Nguyen Xuan Đang, Nguyen Quang Truong, 2010. Diversity of the herpetofauna of Xuan Nha Nature Reserve, Son La Province, Northern Vietnam. Journal of Biology, Hanoi, 32(4): 54-61 (in Vietnamese, summary in English).

9. Nguyen S. V., Ho C. T., Nguyen T. Q., 2009. Herpetofauna of Vietnam. Edition Chimaira, Frankfurt am Main, 768 p.

10. Pauwels O. S. G., Wallach V., David P. \& Chanhome L., 2002. A new species of Oligodon Fitzinger, 1826 (Serpentes, Colubridae) from Southern Peninsular Thailand. The Natural History Journal of Chulalongkorn University, 2(2): 7-18.

11. Pham A. V., Nguyen S. H. L., Nguyen T. Q., 2014. New records of snakes (Squamata: Serpentes) from Son La province, Vietnam. Herpetology Notes, 7: 771-777.

12. Pham Van Anh, Nguyen Thi Bich Ngoc, Nguyen Thi Men, Nguyen Lan Hung Son, Nguyen Quang Truong, 2013. New records of snakes (Reptilia: Squamata: Serpentes) from Son La Province. Proceedings of the $5^{\text {th }}$ National Scientific Conference on Ecology and Biological Resources, Hanoi Agricultural publisher: 16-22 (in Vietnamese, summary in English).

13. Smith M. A., 1943. The fauna of British India, Ceylon and Burma, including the whole of the Indo-Chinese Subregion. Reptilia and Amphibia. Vol. III. Serpentes.
Taylor and Francis (London), 440 p.

14. Tordoff A. W., Tran B. Q., Nguyen T. D., Le H. M. (eds.), 2004. Sourcebook of existing and proposed protected areas in Vietnam. Birdlife International in Indochina and Ministry of Agriculture and Rural Development, Second edition (CD), Hanoi.

15. Vogel G., David P., Pauwels O. S. G., Sumontha M., Norval G., Hendrix R., Vu N. T. \& Ziegler T., 2009. A revision of Lycodon ruhstrati (Fischer, 1886) auctorum (Squamata: Colubridae), with the description of a new species from Thailand and a new subspecies from the Asian mainland. Tropical Zoology, 22: 131-182.

16. Yang, D.-T, Rao D.-Q., 2008. Amphibia and reptilia of Yunnan. Yunnan Publishing Group Corporation, Yunnan Science and Technology Press, $411 \mathrm{p}$.

17. Ziegler T., Vogel G., 1999. On the knowledge and specific status of Dendrelaphis ngansonensis (Bourret, 1935) (Reptilia: Serpentes: Colubridae). Russian Journal of Herpetology, 6(3): 199-208.

18. Ziegler T., Orlov N. L., Giang T. T., Nguyen T. Q., Nguyen T. T., Le Q. K., Nguyen K. V., Vu T. N., 2010. New records of cat snakes, Boiga Fitzinger, 1826 (Squamata, Serpentes, Colubridae), from Vietnam, inclusive of an extended diagnosis of Boiga bourreti Tillack, Le \& Ziegler, 2004. Zoosyst. Evol., 86(2): 263-274. 


\title{
GHI NHậN MỚI PHÂN BỐ CỦA CÁC LOÀI RẮN (Squamata: Serpentes) Ở TỈNH ĐIỆN BIÊN
}

\author{
Lê Trung Dũng ${ }^{1}$, Nguyễn Lân Hùng Sơn ${ }^{1}$, Phạm Thế Cường ${ }^{2}$, Nguyễn Quảng Trường ${ }^{2}$ \\ ${ }^{1}$ Trường Đại học Sư phạm Hà Nội \\ ${ }^{2}$ Viện Sinh thái và Tài nguyên sinh vật, Viện Hàn lâm KH\&CN Việt Nam
}

\section{TÓM TÁT}

Dựa trên phân tích các mẫu vật thu thập được ở Khu Bảo tồn thiên nhiên Mường Nhé, Điện Biên, chúng tôi ghi nhận bổ sung 13 loài rắn, đó là Boiga cyanea, Dendrelaphis ngansonensis, Gonysoma prasinum, Lycodon futsingensis, Oligodon fasciolatus, Oreocryptophis porphyraceus, Rhabdophis nuchalis, $R$. subminiatus, Psammodynastes pulverulentus, Pareas carinatus, P. hamptoni, Pseudoxenodon macrops và Ovophis monticola. Như vậy, cho đến nay, đã có 46 loài rắn được ghi nhận ở tỉnh Điện Biên.

Từ khóa: Ghi nhận mới, hình thái, phân bố, rắn, Điện Biên.

Ngày nhận bài: 10-8-2014 